\title{
Computational Study of the Solid-State Vibrations and Force Field of Magnesium and Calcium Hydroxides
}

\author{
Yoshiyuki Hase* \\ Instituto de Química, Universidade Estadual de Campinas, CP 6154, 13084-862 Campinas - SP, Brazil
}

\begin{abstract}
As vibrações no estado sólido dos hidróxidos de magnésio e cálcio foram estudadas através da análise de coordenadas normais. Usando um campo de força simples, de curto alcance, foram obtidas boas concordâncias entre as frequiências calculadas das vibrações normais e as fundamentais experimentalmente observadas. Algumas bandas fundamentais foram estimadas por meio de cálculos. Os cálculos de freqüência para os três modelos de cluster, através do método Hartree-Fock, indicam que o desdobramento dos estiramentos do grupo hidroxila pelo campo de correlação é principalmente originado em interações entre camadas.
\end{abstract}

The solid-state vibrations of magnesium and calcium hydroxides have been studied by normal coordinate analysis. Using a simple short-range force field, the calculated frequencies of normal vibrations are in good agreement with the experimentally observed fundamentals. Some fundamental bands have been estimated by calculations. Hartree-Fock frequency calculations on three model clusters suggest that the correlation field splitting of the hydroxyl group stretching vibrations mainly originates in the interlayer interactions.

Keywords: magnesium hydroxide, calcium hydroxide, normal coordinate analysis, solidstate vibrations

\section{Introduction}

After a long controversy about interpretation of lowfrequency infrared bands, a new assignment has been proposed for the brucite-type metal hydroxides. ${ }^{1-3}$ According to the empirical linear relationship of the infrared $\mathrm{OH}$ stretching frequencies against physicalchemical data that characterizes the solid-state metal hydroxides, magnesium and calcium hydroxides belong to the same group of hydroxides..$^{4-7}$ This new proposal in assignment of magnesium hydroxide seems to be consistent with the assignment of the calcium analogue by Lutz et al. ${ }^{8}$ With respect to the Raman spectra, the Raman active fundamentals are well established for both the hydroxides by aid of a single crystal Raman polarization measurement. ${ }^{9-11}$ Hence, the fundamental frequencies of the solid-state vibrations of the magnesium and calcium hydroxides are almost completely known from experiment for the normal compounds and their deuterated analogues. Although Oehler and Günthard ${ }^{12}$ reported the frequency calculations of the solid-state

*e-mail: hase@iqm.unicamp.br calcium hydroxide, band assignment of the observed spectral data based on the dispersion surface calculations is not in agreement with the later vibrational analysis. ${ }^{8-11}$

In this article, normal coordinate analysis for single crystals was carried out on the magnesium and calcium hydroxides, using a simple short-range force field. The eight force constants were refined to fit the calculated normal frequencies to the fundamental frequencies observed in the infrared and Raman spectra. The interactions between the polarized $\mathrm{OH}$ groups, which are responsible to correlate field band splitting on the $\mathrm{OH}$ stretching vibrations $(\mathrm{vOH})$, are discussed in terms of the force constants and also based on the quantum chemical calculations performed on three types of clusters.

\section{Crystal structure and selection rule}

Crystal structure of the hydroxide of interest $\left(\mathrm{P} \overline{3} \mathrm{ml} \equiv \mathrm{D}_{3 \mathrm{~d}}^{3}\right)$ is illustrated in Figure 1. The layer structure consists of trigonal sheets of metal ions attached by hydroxide groups on both sides of the sheets. The nearest neighbor layers interact on each other by interlayer force, which mainly arises from electrostatic interactions of the 
closed and oppositely directed hydroxide groups. According to neutron diffraction structural analysis, the lattice constants are $a=3.148 \AA, c=4.779 \AA, z_{\mathrm{O}}=0.2187$ and $z_{\mathrm{H}}=0.4169$ for $\mathrm{Mg}(\mathrm{OH})_{2}$ and $a=3.589 \AA, c=4.911$ $\AA, z_{\mathrm{O}}=0.2337$ and $z_{\mathrm{H}}=0.4256$ for $\mathrm{Ca}(\mathrm{OH})_{2} \cdot{ }^{13,14}$ Since the unit cell of brucite-type crystals contains one formula unit of $\mathrm{M}(\mathrm{OH})_{2}$, factor group analysis at the Brillouin zone center $(\mathbf{k}=0)$ yields the structure of the reduced representation: $\Gamma=2 \mathrm{~A}_{1 \mathrm{~g}}+2 \mathrm{E}_{\mathrm{g}}+2 \mathrm{~A}_{2 \mathrm{u}}+2 \mathrm{E}_{\mathrm{u}}$. The vibrations of $\mathrm{A}_{1 \mathrm{~g}}$ and $\mathrm{E}_{\mathrm{g}}$ species are Raman active, while the vibrations of $\mathrm{A}_{2 \mathrm{u}}$ and $\mathrm{E}_{\mathrm{u}}$ species are active in infrared spectra.

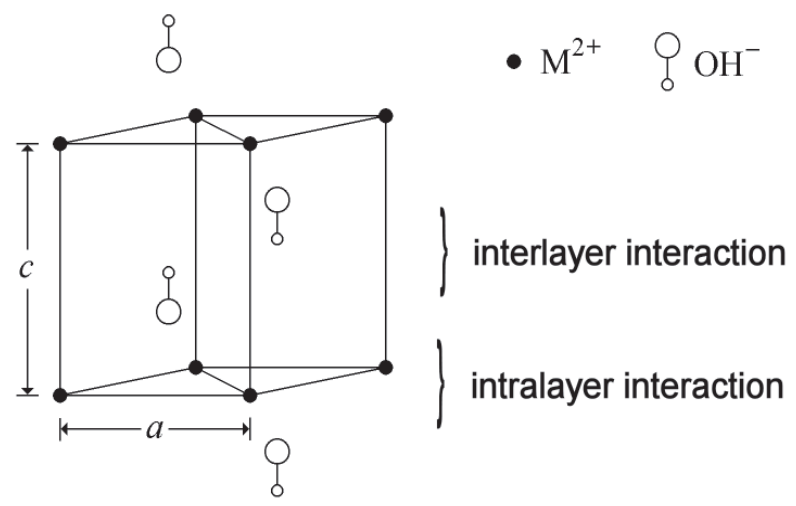

Figure 1. Unit-cell structure of brucite-like $\mathrm{M}(\mathrm{OH})_{2}$, showing lattice constants $a$ and $c$.

\section{Results and Discussion}

Single crystal normal coordinate analysis, based on Cartesian symmetry coordinates, was carried out in accordance to the Wilson's GF matrix method, using the NCT program package. ${ }^{15}$ The short-range force field is expressed by two bond stretch force constants, $\mathrm{f}(\mathrm{OH})$ and $\mathrm{f}(\mathrm{MO})$, and three non-bonded neighbor interactions $\mathrm{f}(\mathrm{H} . . \mathrm{H}), \mathrm{f}(\mathrm{O} \ldots \mathrm{H})$ and $\mathrm{f}(\mathrm{O} \ldots \mathrm{O})$. Three additional crossterms, $\mathrm{f}(\mathrm{OH} / \mathrm{OH}), \mathrm{f}(\mathrm{MO} / \mathrm{OM})$ and $\mathrm{f}(\mathrm{MO} / \mathrm{OM})^{\prime}$, are also necessary for good reproduction of the experimental
Table 1. Force constants (mdyn $\left.\AA^{-1}\right)$

\begin{tabular}{lcccc}
\hline $\begin{array}{l}\text { Force } \\
\text { Constant }\end{array}$ & $\begin{array}{c}\mathrm{Mg}(\mathrm{OH})_{2} \text { and } \mathrm{Mg}(\mathrm{OD})_{2} \\
\text { Set 1 }\end{array}$ & Set 2 & \multicolumn{2}{c}{$\begin{array}{c}\mathrm{Ca}(\mathrm{OH})_{2} \text { and } \mathrm{Ca}(\mathrm{OD})_{2} \\
\text { Set 1 }\end{array}$} \\
\hline $\mathrm{fet}(\mathrm{OH})$ & 7.397 & $7.324(\mathrm{H})$ & 7.315 & $7.254(\mathrm{H})$ \\
$\mathrm{f}(\mathrm{OH} / \mathrm{OH})$ & -0.092 & -0.092 & -0.066 & -0.066 \\
$\mathrm{f}(\mathrm{MO})$ & 0.955 & 0.954 & 0.780 & 0.779 \\
$\mathrm{f}(\mathrm{MO} / \mathrm{OM})$ & 0.367 & 0.367 & 0.274 & 0.273 \\
$\mathrm{f}(\mathrm{MO} / \mathrm{OM})$ & -0.041 & -0.041 & -0.008 & -0.009 \\
$\mathrm{f}(\mathrm{H} \ldots \mathrm{H})$ & 0.077 & 0.077 & 0.071 & 0.071 \\
$\mathrm{f}(\mathrm{O} \ldots \mathrm{H})$ & 0.143 & 0.143 & 0.087 & 0.087 \\
$\mathrm{f}(\mathrm{O} \ldots \mathrm{O})$ & -0.028 & -0.028 & -0.027 & -0.027 \\
\hline
\end{tabular}

fundamentals. Table 1 summarizes the final values of the force constants refined against the experimental frequencies. The observed and calculated frequencies are given in Table 2 (magnesium hydroxide) and Table 3 (calcium hydroxide).

Set 1 force constants were refined with the observed frequencies of both of the normal hydroxide and its deuterium analogue. The values of $\mathrm{f}(\mathrm{OH})$ for the $\mathrm{Mg}$ compound (7.397 mdyn $\AA^{-1}$ ) and the Ca compound (7.315 mdyn $\AA^{-1}$ ) are almost the same. Agreement between the calculated and observed frequencies is very good for such a simple potential function and discrepancies are found only in the hydroxyl group stretching bands. Set 2 force constants were determined similarly, but based on a consideration that the value of $\mathrm{f}(\mathrm{OH})$ can be different between the $\mathrm{OH}$ and $\mathrm{OD}$ compounds, possibly to compensate the effect of an anharmonicity under harmonic approximations. The hydroxyl group stretching frequencies become very close to the experimental fundamentals. It is worth noting that the differentiated $\mathrm{f}(\mathrm{OH})$ force constants do not affect the optimized values of the remaining force constants, consequently the frequencies of the external vibrations. The ratios of $\mathrm{f}(\mathrm{OH})$ between isotopic hydroxides $(7.534 / 7.324=1.029$ for $\mathrm{Mg}$ and 7.429/7.254 = 1.024 for $\mathrm{Ca}$ ) are comparable to the mean value (1.026) computed for diverse molecular systems. ${ }^{16}$

Table 2. Observed and calculated frequencies $\left(\mathrm{cm}^{-1}\right)$ of magnesium hydroxide

\begin{tabular}{|c|c|c|c|c|c|c|c|c|}
\hline & \multicolumn{4}{|c|}{$\mathrm{Mg}(\mathrm{OH})_{2}$} & \multicolumn{4}{|c|}{$\mathrm{Mg}(\mathrm{OD})_{2}$} \\
\hline & \multicolumn{2}{|c|}{ Obs. } & \multicolumn{2}{|c|}{ Calc. } & \multicolumn{2}{|c|}{ Obs. } & \multicolumn{2}{|c|}{ Calc. } \\
\hline & $\operatorname{Raman}^{\mathrm{a}}$ & Infrared $^{\mathrm{b}}$ & Set 1 & Set 2 & $\operatorname{Raman}^{\mathrm{a}}$ & Infrared $^{\mathrm{b}}$ & Set 1 & Set 2 \\
\hline \multirow[t]{2}{*}{$A_{1 g}$} & 3652 & & 3673 & 3655 & 2696 & & 2668 & 2692 \\
\hline & 443 & & 445 & 444 & 434 & & 433 & 433 \\
\hline \multirow{2}{*}{$E_{g}$} & 725 & & 720 & 720 & 506 & & 513 & 513 \\
\hline & 280 & & 279 & 279 & 277 & & 278 & 278 \\
\hline \multirow[t]{2}{*}{$A_{2 u}$} & & $3698 \mathrm{~s}$ & 3713 & 3695 & & $2725 \mathrm{~s}$ & 2705 & 2729 \\
\hline & & $562 \mathrm{w}$ & 562 & 562 & & $(549)^{c}$ & 555 & 555 \\
\hline \multirow[t]{2}{*}{$\mathrm{E}_{\mathrm{u}}$} & & $462 \mathrm{~s}$ & 461 & 462 & & $410 \mathrm{~s}$ & 406 & 406 \\
\hline & & $368 \mathrm{~s}$ & 373 & 373 & & $305 \mathrm{~s}$ & 305 & 305 \\
\hline
\end{tabular}

a Reference 9; ${ }^{b}$ reference 2; ' shoulder band (not used for refinement). 
Table 3. Observed and calculated frequencies $\left(\mathrm{cm}^{-1}\right)$ of calcium hydroxide

\begin{tabular}{|c|c|c|c|c|c|c|c|c|}
\hline & \multicolumn{4}{|c|}{$\mathrm{Ca}(\mathrm{OH})_{2}$} & \multicolumn{4}{|c|}{$\mathrm{Ca}(\mathrm{OD})_{2}$} \\
\hline & \multicolumn{2}{|c|}{ Obs. } & \multicolumn{2}{|c|}{ Calc. } & \multicolumn{2}{|c|}{ Obs. } & \multicolumn{2}{|c|}{ Calc. } \\
\hline & $\operatorname{Raman}^{\mathrm{a}}$ & Infrared $^{\mathrm{b}}$ & Set 1 & Set 2 & $\operatorname{Raman}^{\mathrm{a}}$ & Infrared $^{\mathrm{b}}$ & Set 1 & Set 2 \\
\hline \multirow{2}{*}{$\overline{A_{1 g}}$} & 3620 & & 3634 & 3619 & 2661 & & 2643 & 2663 \\
\hline & 357 & & 359 & 358 & 350 & & 349 & 349 \\
\hline \multirow[t]{2}{*}{$\mathrm{E}_{\mathrm{g}}$} & 680 & & 676 & 676 & 475 & & 480 & 480 \\
\hline & 254 & & 254 & 254 & 252 & & 252 & 252 \\
\hline \multirow[t]{2}{*}{$\mathrm{A}_{2 \mathrm{u}}$} & & 3645 & 3661 & 3646 & & 2689 & 2667 & 2686 \\
\hline & & $(415)^{\mathrm{c}}$ & 418 & 418 & & 411 & 411 & 411 \\
\hline \multirow[t]{2}{*}{$\mathrm{E}_{\mathrm{u}}$} & & 392 & 391 & 392 & & $(303)^{\mathrm{d}}$ & 347 & 347 \\
\hline & & 312 & 312 & 312 & & $(275)^{d}$ & 253 & 253 \\
\hline
\end{tabular}

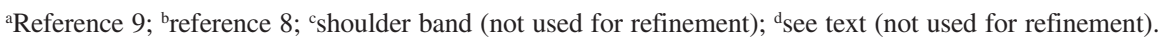

To describe the weak interaction functions between hydroxyl group sheets, two types of forces might be considered; non-bonded forces acting between two near neighbor atoms and the dipole-dipole interaction force. Inclusion of three atom-atom neighbor interaction force constants $\mathrm{f}(\mathrm{H} \ldots \mathrm{H}), \mathrm{f}(\mathrm{O} \ldots \mathrm{H})$ and $\mathrm{f}(\mathrm{O} \ldots \mathrm{O})$ is necessary to reproduce some external vibration frequencies. However, these terms alone are insufficient to express an effective correlation field band splitting observed for the $\mathrm{OH}$ stretching vibrations. On the other hand, the dipole-dipole interaction force constant $\mathrm{f}(\mathrm{OH} / \mathrm{OH})$ does not contribute in any way to the lattice modes of vibration, but the small values, -0.092 mdyn $\AA^{-1}(\mathrm{Mg})$ and -0.066 mdyn $\AA^{-1}(\mathrm{Ca})$, are needed and cause correlation field separation of the $\mathrm{OH}$ stretching bands.

In normal coordinate analysis in the form applied in the present study, however, the $\mathrm{OH} / \mathrm{OH}$ interaction term is interpretable as a case of close-neighbor interlayer interactions, as an intra-layer interaction of two opposite side hydroxyl anions on same metal ion plane or as the global sum of two types of interactions. Then, to understand better the correlation field splitting, ab-initio calculations were performed at the Hartree-Fock (HF) level for the three cluster models illustrated in Figure 2, $\left[\mathrm{M}_{8}(\mathrm{OH})_{2}\right]^{14+}$, $\left[\mathrm{M}_{10}(\mathrm{OH})_{2}\right]^{18+}$ and $\left[\mathrm{M}_{16}(\mathrm{OH})_{6}\right]^{26+}$, by the GAMESS program, ${ }^{17}$ using the valence only basis sets with core effective potentials CEP-31G for $\mathrm{Mg}$ and $\mathrm{Ca}$, while the 6-31G standard Pople valence split basis sets were used for $\mathrm{O}$ and $\mathrm{H}$. Additional polarization and diffuse functions were also considered in these calculations. During geometry optimization, all metal-oxygen distances were kept unchanged to the values given by neutron diffraction studies, ${ }^{13,14}$ whereas moving hydrogen atoms along the caxis was allowed to optimize the $\mathrm{OH}$ bond distances. Analytical frequency calculations were performed for the respective optimized cluster structures. Although, the $\mathrm{OH}$ stretching frequencies might be useful to interpret the effect of the correlation field on the $\mathrm{vOH}$ bands, the external normal vibrations computed for such model calculations are, of course, meaningless and not analyzed. (a)

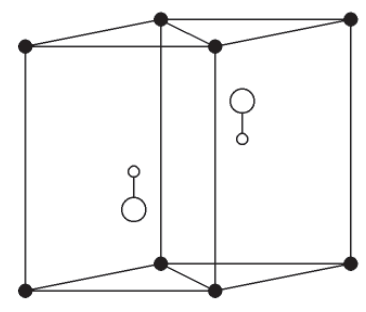

(b)

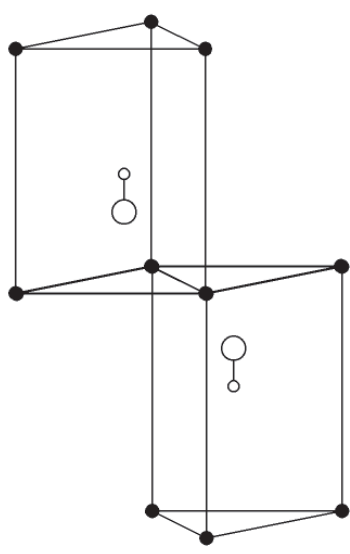

(c)

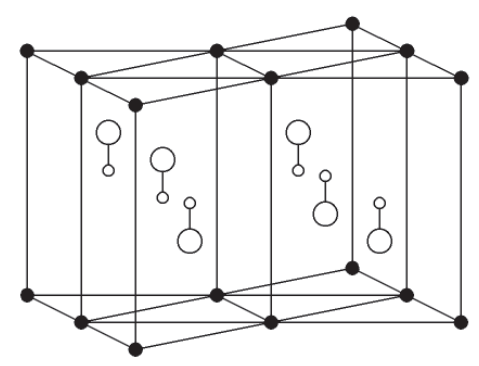

Figure 2. Model clusters: (a) $\left[\mathrm{M}_{8}(\mathrm{OH})_{2}\right]^{14+}$, (b) $\left[\mathrm{M}_{10}(\mathrm{OH})_{2}\right]^{18+}$ and (c) $\left[\mathrm{M}_{16}(\mathrm{OH})_{6}\right]^{26+}$. 
Table 4. Basis set, ab-initio OH stretching wavenumbers (in $\mathrm{cm}^{-1} ; \widetilde{v}_{\mathrm{u}}$, out of phase; $\widetilde{v}_{\mathrm{g}}$, in phase) and correlation field splitting $\left(\Delta \widetilde{\mathrm{v}}=\widetilde{\mathrm{v}}_{\mathrm{u}}-\widetilde{\mathrm{v}}_{\mathrm{g}}\right)$ of $\left[\mathrm{M}_{8}(\mathrm{OH})_{2}\right]^{14+}$, $\left[\mathrm{M}_{10}(\mathrm{OH})_{2}\right]^{18+}$ and $\left[\mathrm{M}_{16}(\mathrm{OH})_{6}\right]^{26+}$ clusters

\begin{tabular}{|c|c|c|c|c|c|c|c|c|c|c|}
\hline \multicolumn{2}{|c|}{ Bases set } & \multicolumn{3}{|c|}{$\left[\mathrm{Mg}_{8}(\mathrm{OH})_{2}\right]^{14+}$} & \multicolumn{3}{|c|}{$\left[\mathrm{Mg}_{10}(\mathrm{OH})_{2}\right]^{18+}$} & \multicolumn{3}{|c|}{$\left[\mathrm{Mg}_{16}(\mathrm{OH})_{6}\right]^{26+}$} \\
\hline $\mathrm{Mg}$ & $\mathrm{O}, \mathrm{H}$ & $\tilde{\mathrm{v}}_{\mathrm{u}}$ & $\tilde{v}_{g}$ & $\Delta \tilde{\mathrm{v}}$ & $\widetilde{v}_{\mathrm{u}}$ & $\widetilde{v}_{g}$ & $\Delta \widetilde{v}$ & $\widetilde{v}_{\mathrm{u}}$ & $\tilde{v}_{g}$ & $\Delta \tilde{\mathrm{V}}$ \\
\hline CEP-31G & $6-31 \mathrm{G}$ & 4244 & 4231 & 13 & 4279 & 4277 & 2 & 4027 & 4008 & 19 \\
\hline CEP-31G* & $6-31+\mathrm{G}^{*}$ & 4271 & 4259 & 12 & 4309 & 4307 & 2 & 4057 & 4043 & 14 \\
\hline CEP-31G* & $6-31++\mathrm{G}^{* *}$ & 4332 & 4317 & 15 & 4376 & 4375 & 1 & 4109 & 4092 & 17 \\
\hline \multicolumn{2}{|c|}{ Bases set } & \multicolumn{3}{|c|}{$\left[\mathrm{Ca}_{8}(\mathrm{OH})_{2}\right]^{14+}$} & \multicolumn{3}{|c|}{$\left[\mathrm{Ca}_{10}(\mathrm{OH})_{2}\right]^{18+}$} & \multicolumn{3}{|c|}{$\left[\mathrm{Ca}_{16}(\mathrm{OH})_{6}\right]^{26+}$} \\
\hline $\mathrm{Ca}$ & $\mathrm{O}, \mathrm{H}$ & $\widetilde{v}_{\mathrm{u}}$ & $\widetilde{v}_{g}$ & $\Delta \tilde{\nu}$ & $\tilde{v}_{u}$ & $\tilde{v}_{\mathrm{g}}$ & $\Delta \widetilde{V}$ & $\widetilde{v}_{u}$ & $\tilde{v}_{g}$ & $\Delta \widetilde{v}$ \\
\hline CEP-31G & $6-31 \mathrm{G}$ & 4169 & 4165 & 4 & 4182 & 4178 & 4 & 4044 & 4033 & 11 \\
\hline CEP-31G* & $6-31+\mathrm{G}^{*}$ & 4240 & 4235 & 5 & 4250 & 4246 & 4 & 4095 & 4084 & 11 \\
\hline CEP-31G* & $6-31++\mathrm{G}^{* *}$ & 4311 & 4304 & 7 & 4326 & 4322 & 4 & 4155 & 4143 & 12 \\
\hline
\end{tabular}

Figure 2(a) is a cluster $\left[\mathrm{M}_{8}(\mathrm{OH})_{2}\right]^{14+}$ to estimate close interlayer interaction of one hydroxyl group pair surrounded by metal ions, while the intra-layer pair interaction is modeled as a cluster $\left[\mathrm{M}_{10}(\mathrm{OH})_{2}\right]^{18+}$ in Figure 2(b). Table 4 summarizes the calculated $\mathrm{vOH}$ frequencies and the splitting $\left(\Delta \widetilde{V}=\widetilde{v}_{u}-\widetilde{v}_{g}\right)$ between the asymmetric $\left(\widetilde{v}_{u}\right)$ and symmetric $\left(\widetilde{v}_{g}\right)$ modes for the basis sets employed in this study. The experimental correlation field separations, between the infrared and Raman active $\mathrm{O}-\mathrm{H}$ stretching bands, are $46 \mathrm{~cm}^{-1}$ for $\mathrm{Mg}(\mathrm{OH})_{2}$ and $29 \mathrm{~cm}^{-1}$ for $\mathrm{Mg}(\mathrm{OD})_{2}$ (Table 2). ${ }^{2,9}$ The theoretically simulated separations of $\sim 10 \mathrm{~cm}^{-1}$ are counted to $\left[\mathrm{Mg}_{8}(\mathrm{OH})_{2}\right]^{14+}$ and few wavenumbers are to $\left[\mathrm{Mg}_{10}(\mathrm{OH})_{2}\right]^{18+}$. So that, it is found that the intra-layer interaction force is too small to explain the correlation field. The aspect is different for calcium hydroxide, only some wavenumbers of separation are computed for both clusters, $\left[\mathrm{Ca}_{8}(\mathrm{OH})_{2}\right]^{14+}$ and $\left[\mathrm{Ca}_{10}(\mathrm{OH})_{2}\right]^{18+}$, nevertheless the experimental $\Delta \widetilde{v}$ is measured as 25 $\mathrm{cm}^{-1}$ for $\mathrm{Ca}(\mathrm{OH})_{2}$ and $27 \mathrm{~cm}^{-1}$ for $\mathrm{Ca}(\mathrm{OD})_{2}$ (Table 3). ${ }^{8,9}$ Hence, further calculations were performed on the interlayer system using an extended $\left[\mathrm{M}_{16}(\mathrm{OH})_{6}\right]^{26+}$ cluster in which each central hydroxyl group is surrounded by three groups of neighbor layers, just as seen in crystals. The band separation between two central hydroxyl vibrations is about $15 \mathrm{~cm}^{-1}$ for this $\left[\mathrm{Mg}_{16}(\mathrm{OH})_{6}\right]^{26+}$ cluster, larger than the value for $\left[\mathrm{Mg}_{8}(\mathrm{OH})_{2}\right]^{14+}$, and is approximately half of the experimental band splitting. For the $\left[\mathrm{Ca}_{16}(\mathrm{OH})_{6}\right]^{26+}$ cluster, a band separation of about $10 \mathrm{~cm}^{-1}$ is calculated, also approximately half of the experimental value. Then, it is concluded that the crystal correlation effect on the $\mathrm{nOH}$ fundamentals is principally due to interlayer forces between the piled hydroxyl groups. The larger band splitting in magnesium hydroxide compared with the splitting in calcium hydroxide obtained from the calculation is consistent with the experimental observation.
With respect to the cation-anion interactions, the metaloxygen bond force constants, $\mathrm{f}(\mathrm{MO})$, are 0.955 mdyn $\AA^{-1}$ $(\mathrm{Mg})$ and $0.780 \mathrm{mdyn}^{-1}(\mathrm{Ca})$. The difference of about $20 \%$ indicates that the MO stretching band frequencies are not simply explained by the metal atomic masses, but also essentially due to the MO bonding character. Two metal-oxygen bond-bond interaction force constants, $\mathrm{f}(\mathrm{MO} / \mathrm{OM})$ and $\mathrm{f}(\mathrm{MO} / \mathrm{OM})$ ', describe cis-interaction between two M-O bonds connected to a common metal atom in an $\mathrm{MO}_{6}$ octahedral coordination structural unit. The first, $\mathrm{f}(\mathrm{MO} / \mathrm{OM})$, relates to the same side hydroxyl groups attached about the metal ion sheet, the second, $\mathrm{f}(\mathrm{MO} / \mathrm{OM})^{\prime}$, is between two opposite side hydroxyl groups. The former interaction force, $0.367 \mathrm{mdyn}^{\circ} \AA^{-1}(\mathrm{Mg})$ and 0.274 mdyn $\AA^{-1}(\mathrm{Ca})$, has an important contribution to express the potential function of the brucite-type hydroxides, while the opposite side interaction force, -0.041 mdyn $^{-1}(\mathrm{Mg})$ and -0.008 mdyn $\AA^{-1}(\mathrm{Ca})$, carries a complementary role.

The normal coordinate analysis predicted values of the experimentally uncertain fundamental frequencies are included in Tables 2 and 3. In the case of magnesium hydroxide, only one infrared active $A_{2 u}$ frequency of $\mathrm{Mg}(\mathrm{OD})_{2}$ is missing. The computed frequency of 555 $\mathrm{cm}^{-1}$ is close to the estimated one at $549 \mathrm{~cm}^{-1}$, which was derived from the corresponding $\mathrm{Mg}(\mathrm{OH})_{2}$ weak band at $562 \mathrm{~cm}^{-1}$ by application of the isotope product rule and located on high wavenumber side shoulder of the asymmetrically broad band at $410 \mathrm{~cm}^{-1} \cdot{ }^{2,3}$ In $\mathrm{Ca}(\mathrm{OH})_{2}$, the calculated low-frequency $\mathrm{A}_{2 \mathrm{u}}$ mode of 418 $\mathrm{cm}^{-1}$ is in agreement with the assignment of $\sim 415 \mathrm{~cm}^{-1}$ on shoulder of the strong and broad band at $392 \mathrm{~cm}^{-1}$ and shifts to $411 \mathrm{~cm}^{-1}$ on deuteration. ${ }^{8}$ Lutz et al. assigned two infrared bands of $\mathrm{Ca}(\mathrm{OH})_{2}$ at 392 and 312 $\mathrm{cm}^{-1}$ as the $\mathrm{E}_{\mathrm{u}}$ fundamentals. On the other hand, the infrared spectra of $\mathrm{Ca}(\mathrm{OD})_{2}$ give only one band (303 $\mathrm{cm}^{-1}$ ) at room temperature, while two peaks (310 and $265 \mathrm{~cm}^{-1}$ ) are found at $95 \mathrm{~K}$. So that, the $\mathrm{E}_{\mathrm{u}}$ bands of 
$\mathrm{Ca}(\mathrm{OD})_{2}$ were not used to refine the force constants. The calculated $\mathrm{E}_{\mathrm{u}}$ frequencies for the optimized force constants are 347 and $253 \mathrm{~cm}^{-1}$; those are not in good agreement with the experimental fundamental frequencies.

\section{Conclusions}

The results of normal coordinate analysis supported the band assignments of the solid-state vibrations of magnesium and calcium hydroxides proposed in literature. ${ }^{2,8,9}$ The calculated frequencies are in good agreement with the fundamentals observed in both internal and external vibrations and well-reproduced isotopic shifts of the infrared and Raman bands. Some experimentally uncertain fundamental band positions were also predicted by normal coordinate calculations.

The refined force field parameters showed that the dipole-dipole interaction force constant $\mathrm{f}(\mathrm{OH} / \mathrm{OH})$ was necessary to express the correlation field band splitting of the $\mathrm{OH}$ stretching vibrations. Moreover, the HartreeFock cluster model calculations revealed that the interlayer interactions of the hydroxyl groups are responsible to this correlation effect. On the other hand, the neighbor atom-atom interaction force constants $\mathrm{f}(\mathrm{H} \ldots \mathrm{H}), \mathrm{f}(\mathrm{O} \ldots \mathrm{H})$ and $\mathrm{f}(\mathrm{O} \ldots \mathrm{O})$ were needed to estimate the low-frequency lattice vibrations.

\section{Acknowledgments}

This work was financially supported in part by FAEP/ UNICAMP. Professor C. H. Collins' assistance in revising this manuscript is gratefully acknowledged.

\section{References}

1. Mockenhaupt, C.; Zeiske, T.; Lutz, H. D.; J. Mol. Struct. 1998, 443, 191.

2. de Oliveira, E. F.; Hase, Y.; Vib. Spectrosc. 2001, 25, 53.

3. de Oliveira, E. F.; Hase, Y.; Vib. Spectrosc. 2003, 31, 19.

4. Ryskin, Ya. I.; Stavitskaya, G. P.; Opt. Spectrosc. 1981, 50, 216.

5. Trokhimets, A. I.; Russ. J. Appl. Spectrosc. 1983, 39, 1059.

6. Brindley, G. W.; Kao, C.-C.; Phys. Chem. Minerals 1984, 10, 187.

7. Beckenkamp, K.; Lutz, H. D.; J. Mol. Struct. 1992, 270, 393.

8. Lutz, H. D.; Holler, H.; Schmidt, M.; J. Mol. Struct. 1994, 328, 121.

9. Dawson, P.; Hadfield, C. D.; Wilkinson, G. R.; J. Phys. Chem. Solids 1973, 34, 1217.

10. Padanyi, Z. V.; Solid State Commun. 1970, 8, 541.

11. Dawson, P.; Solid State Commun. 1972, 10, 41.

12. Oehler, O.; Günthard, Hs. H.; J. Chem. Phys. 1968, 48, 2036.

13. Desgranges, L.; Calvarin, D.; Chevier, G.; Acta Crystallogr. 1996, B52, 82 .

14. Desgranges, L.; Grebille, D.; Calvarin, G.; Chevier, G.; Floquet, G.; Niepce, J. C.; Acta Crystallogr. 1993, B49, 812.

15. Hase, Y.; Quim. Nova 2004, 27, 664.

16. Shimanouchi, T.; Suzuki, I.; J. Chem. Phys. 1965, 42, 296.

17. Schmidt, W.; Baldridge, K. K.; Boatz, J. A.; Elbert, S. T.; Gordon, M. S.; Jensen, J. H.; Koseki, S.; Matsunaga, N.; Nguyen, K. A.; Su, S. J.; Windus, T. L.; Dupuis, M.; Montgomery, J. A.; J. Comput. Chem. 1993, 14, 1347.

Received: July 20, 2005

Published on the web: May 26, 2006

FAPESP helped in meeting the publication costs of this article. 